(C) [2008] IEEE. Reprinted, with permission, from [Essam Rahali, Zenon Chaczko, Johnson Agbinya, Christopher Chiu, Business Process Re-engineering in Saudi Arabia: A Survey of Understanding and Attitudes, 2008, Third International Conference on Broadband Communications, Information Technology \& Biomedical Applications, 2008]. This material is posted here with permission of the IEEE. Such ermission of the IEEE does not in any way imply IEEE endorsement of any of the University of Technology, Sydney's products or services. Internal or personal use of this material is permitted.However, permission to reprint/republish this material for advertising or promotional purposes or for creating new collective works for resale or redistribution must be obtained from the IEEE by writing to pubspermissions@ieee.org. By choosing to view this document, you agree to all provisions of the copyright laws protecting it 


\title{
Business Process Re-engineering in Saudi Arabia: A Survey of Understanding and Attitudes
}

\author{
Essam Rahali ${ }^{1}$, Zenon Chaczko ${ }^{2}$, Johnson Agbinya ${ }^{3}$, Christopher Chiu ${ }^{4}$ \\ ${ }^{1}$ Essam Rahali, \\ Faculty of Engineering, \\ University of Technology, \\ Sydney, Australia, \\ essam.rahali@uts.edu.au \\ ${ }^{2}$ Johnson Agbinya, \\ ICT Group, \\ Faculty of Engineering, \\ University of Technology, \\ Sydney, Australia, \\ johnson.agbinya@uts.edu.au \\ ${ }^{3}$ Christopher Chiu, \\ Faculty of Engineering, \\ University of Technology, \\ Sydney, Australia, \\ christopher.c.chiu@uts.edu.au
}

\begin{abstract}
This survey was conducted in the Kingdom of Saudi Arabia (KSA) to investigate the level of awareness of BPR. Respondents (customers, employees, and managers) had different educational backgrounds and were from private and public sectors. Findings of the study indicate a general awareness of BPR in KSA.
\end{abstract}

Keywords: Business Processes, Business Process Reengineering, BPR, Information Technology

\section{INTRODUCTION}

Business process reengineering (BPR) is the result of a new process-orientation that is trying to overcome some of the problems raised by Taylor's traditional view of structural specialisation. It stresses the radical change of processes concerning different departments. However, the redesign of processes is only one aspect of the management of business processes. At least three different kinds of process management can be identified: the management of ongoing business processes, the improvement of business processes and the re-engineering of business processes [1]. In order to reengineer a business process, both internal and external process capabilities; such as product development, production, distribution suppliers and markets, and inter-organisational relationships; especially in a global manufacturing environment, need to be integrated.

The purpose of re-engineering is to achieve lean production by integrating production activities into self-contained units along the production flow, with Information Technology an important element [4]. Information Technology holds a key integral factor in developing data integration strategies in various legacy systems and current technology frameworks. Systems need to reflect a Service-OrientedArchitecture approach to effectively manage resources to enhance work practices, and provide optimal feedback mechanisms to improve efficiency and conform to ISO environmental standards [21]. Universal middleware standards, including Web Services play a key role in integrating autonomous systems in a global scale for multinational companies.
By harmonising data exchange mechanisms, real-time information can be relayed to a managing authority that can respond to changes in system behaviour before tolerance thresholds reach unacceptable levels, potentially avoiding environmental tragedies in volatile industries such as petroleum refineries.

Transformation involves changing many of our assumptions and principles of management and reexamining the nature of work and workers. Jobs should be organised around outcomes, not tasks. Individuals should be empowered to use discretion and judgment in performing their duties and obligations. Control, accountability, and processing must be built into the work process so that individual efforts contribute directly to the success of the organisation [2]. There are several reasons for organisations to re-engineer their business processes:

1. to re-invent work methods to satisfy customers;

2. to be consistently competitive;

3. cure systemic process and behavioural problems;

4. enhance capability to expand in other industries;

5. to accommodate an era of change;

6. to satisfy their customers, employees, and other stakeholders who want them to be dramatically different and/or to produce different results,

7. to survive and be successful in the long term; and

8. to invent the "rules of the game" [3].

In Hammer and Champy [20], they argue the labour division model designed in the nineteenth century simply do not work as companies enter the twentyfirst century. They present concepts of redesigning business processes and propose to move the organisation from a narrow mesh of task-oriented jobs to one comprised of multi-dimensional jobs where workers are expected to think, take responsibility, and act accordingly [5]. They cite three reasons:

- $\quad$ Firstly, Processes tied with $21^{\text {st }}$ century products and services are complex and require many tasks.

- Secondly, several management layers are needed for coordination, which creates "distance" between customers and management.

- Finally, as task decomposition and coordination becomes an intricate process, adapting it to changes in environment becomes more difficult. 


\section{DEFINITION OF BPR}

Hammer and Champy [20] noted that in the business environment, nothing is constant or predictable-not market growth, customer demand, product life spans, technological change, or the nature of competition. As a result, customers, competition, and change have taken on entirely new dynamics in the business world. Customers now have choice, and they expect products to be customised to their unique needs. Competition, no longer decided by "best price" alone, is driven by other factors such as quality, selection, service, and responsiveness. In addition, rapid change has diminished product and service life cycles, making the need for inventiveness and adaptability even greater. This mercurial business environment requires a switch from a task orientation to a process orientation, and it requires re- inventing how work is to be accomplished. As such, reengineering focuses on fundamental business processes, as opposed to departments or organisational units [2].

According to Hammer and Champy, reengineering is defined as "The fundamental rethinking and radical redesign of business processes to achieve dramatic improvements in critical contemporary measures of performance, such as cost, quality, service and speed”. In other words, they proposed a radical shift: rather than defining a business by the products or services it produces, businesses are defined by what they do well. They believed such a view of business barriers to growth as businesses found new ways to adapt what they did well to new markets. It also eliminated the gap between strategy and implementation since senior management no longer simply set goals but had to understand exactly what goals to achieve. Reengineering, like restructuring, is a method of revolutionary change and thus embodies all general features of such radical changes [6].

BPR has contributed to the provision of techniques for continuous improvement [20]. Since technology is constantly advancing, and the business environment is constantly changing, processes and the systems supporting them are in need of methods to facilitate and guide their parallel improvement. This in turn enables businesses to focus on the customer and adapt to the customer's changing requirements (Hammer, 1993; Harrington, 1991). In a business environment, where the customers' needs are driving forces, BPR provides business organisations with the opportunity to adjust dynamically to customer demands [7].

Chan and Peel (1998) conducted a survey of 37 companies in 17 different industries to investigate the causes and the impact of BPR. They concluded that the primary reasons for BPR are increasing efficiency (internal) and improving customer service (external). Francis and McIntosh (1997) identified causes for the emergence of BPR such as customers, competition (global), technological development and IT. Most companies are function or department-oriented, and not process-oriented. Often, many people are involved in order fulfilment, but nobody tracks a product and reports the status of an order directly. Reengineering makes one individual responsible for the complete business process (Self, 1995). In another study, the success of BPR is related to the creativity of the people in the organisation (Paper, 1997). Some of the factors that will prevent reengineering and hence innovation and growth are:
i. correcting the process instead of changing it;
ii. loss of nerve;
iii. the barons;
iv. change of company champion;
v. $\quad$ settling for minor results;
vi. culture, attitudes and skill-base;
vii. skimping on resources; and
viii. pulling back when people resist change [8].

\section{SUCCESSFUL IMPLEMENTATIONS OF BPR}

Business process reengineering means moving from the 'assembly-line approach' to the bundledresponsibility or task-subsuming approach, where a process is overseen and handled by key people doing this job from start to end [9]. The fundamental pattern is to widen individual responsibility in the sense of job enlargement in order to meet marketdriven needs. This is an extension of Herzberg's concept of job enlargement [10]. Reengineering is the fundamental rethinking and radical redesign of business processes to achieve dramatic improvements in critical, contemporary measures of performance, such as cost, quality, service and speed. BPR advocates that enterprises go back to the basics and re-examine their very roots. It doesn't believe in small improvements, but rather it aims at total reinvention.

As for results, BPR is clearly not for companies who want a $10 \%$ improvement. It is for those who need a ten-fold increase. BPR can succeed only when the importance of both people skills and technical skills is fully recognised, and both are properly applied. Many attempts at reengineering have failed because this has not been understood [11]. Empirical studies provide mixed evidence regarding the success of BPR

On the one hand, researchers at Computer Sciences Corporation index (CSCIndex) reported that approximately one-fourth of the re-engineering projects they had studied in North America were not meeting their goals (Cafasso, 1993). In another industry survey conducted by Deloitte \& Touché in 1993, Chief Information Officers (CIOs) indicated that the actual benefits of BPR projects had generally fallen short of expectations [12]. 
According to Hammer and Champy [20]; BPR focuses on processes and not on tasks, jobs or people. It endeavours to redesign the strategic and value added processes that transcend organisational boundaries [13]. An organisation creates value through its processes. BPR provides a method for work groups to identify and prioritise issues and concerns in work processes. Many articles point out that BPR must have the full support of top management to succeed. If resistance is encountered, the leader must be willing to drive change, even to the point of ruthlessness. Managers in a company undergoing reorganisation must work to quell the fears of employees and resistance to change (despite the fact that they may have their own apprehensions) [14]. It also provides a structure for employees for all levels in the organisation to have open dialogue regarding those issues and concerns. BPR causes an organisation to become introspective and assess how it does its business and utilises its staff. BPR also helps business units to begin preparing for managed competition by streamlining processes and optimising the use of employees [15].

The progression of BPR concept from theory to sustained practice is dependent on the development of its theoretical base, and the introduction of methodological approaches that are capable of being used by practitioners [16]. Andrews and Stalick (1992) have argued for a systemic approach to BPR, suggesting that "reengineering...should be based upon numbers and facts, not guts and politics". BPR projects cannot be planned meticulously and organised into precise steps which can be prescribed as universally applicable in all situations (Caron et. al., 1994; Hammer, 1990). Nevertheless, since BPR requires a fundamental reappraisal of business operations, a methodology which can act as an anchoring framework to coordinate the complex web of BPR activities is essential.

A clear and committed approach to BPR is necessary, but a possible danger identified in the literature is that those involved in the BPR project will confuse motion with progress, and charge about in random directions hoping that any recommended changes can be successfully implemented as a matter of course (Evans, 1993). Caron et. al. (1994) state that implementing BPR recommendations may require a fundamental change in organisational culture and mind-set and this cannot be left to chance, but must be carefully managed. They also argue that visibility into the BPR exercise is vital and must intensify as the project proceeds. Thus, the adoption of some methodological support is appropriate [17].

There are nine major elements considered by experts to be stepping stones to successful business process reengineering. They cover a wide range of activities, such as identifying customer needs and performance problems, reassessing strategic goals, defining reengineering opportunities, managing reengineering projects, controlling risks and maximising benefits, managing organisational changes, and successfully implementing new processes. Taken together, these nine elements provide a general framework for assessing a reengineering project, from initial strategic planning and goal-setting to postimplementation assessments [17].

According to the BPR Online Learning Centre, more than half of early reengineering projects failed to be completed or did not achieve bottom-line business results, and for this reason business process reengineering "success factors" have become an important area of study. The success factors below are derived from benchmarking studies with more than 150 companies over a 24 month period. Success factors are a collection of lessons learned from reengineering projects. These success factors are [18]:

- Top Management Sponsorship (strong, consistent involvement).

- $\quad$ Strategic Alignment (strategic direction).

- Compelling Business Case for Change (with measurable objectives).

- $\quad$ Proven Methodology (includes a vision process).

- Effective Change Management (address cultural transformation)

- Line Ownership (pair ownership with accountability).

- Reengineering Team Composition (in both breadth and knowledge).

\section{BUSINESS PROCESS RE- ENGINEERING CONCEPTS IN KSA}

It is well known that the concept of BPR is currently very topical and is ubiquitous in recent organisational, management and information technology literature. The extent of the widespread popular interest in the BPR can be gauged from the fact that Hammer and Champy's recent book on Business process reengineering featured at the top of the US best-seller lists [19]. The researcher conducted a survey from January 2007 to October 2007 to study the level of awareness of BPR in Saudi Arabia and to what extent this concept is perceived as a fundamental approach to design business processes. This comprised of 88 respondents from Saudi and non-Saudi individuals, from the private and public sector in three groups:

a. Customers,

b. Managers, and

c. Employees (Refer to Table 1).

Respondents had different educational backgrounds, ranging from doctoral certifications to high school level. In Table 2, it shows respondents categories and their educational level. 

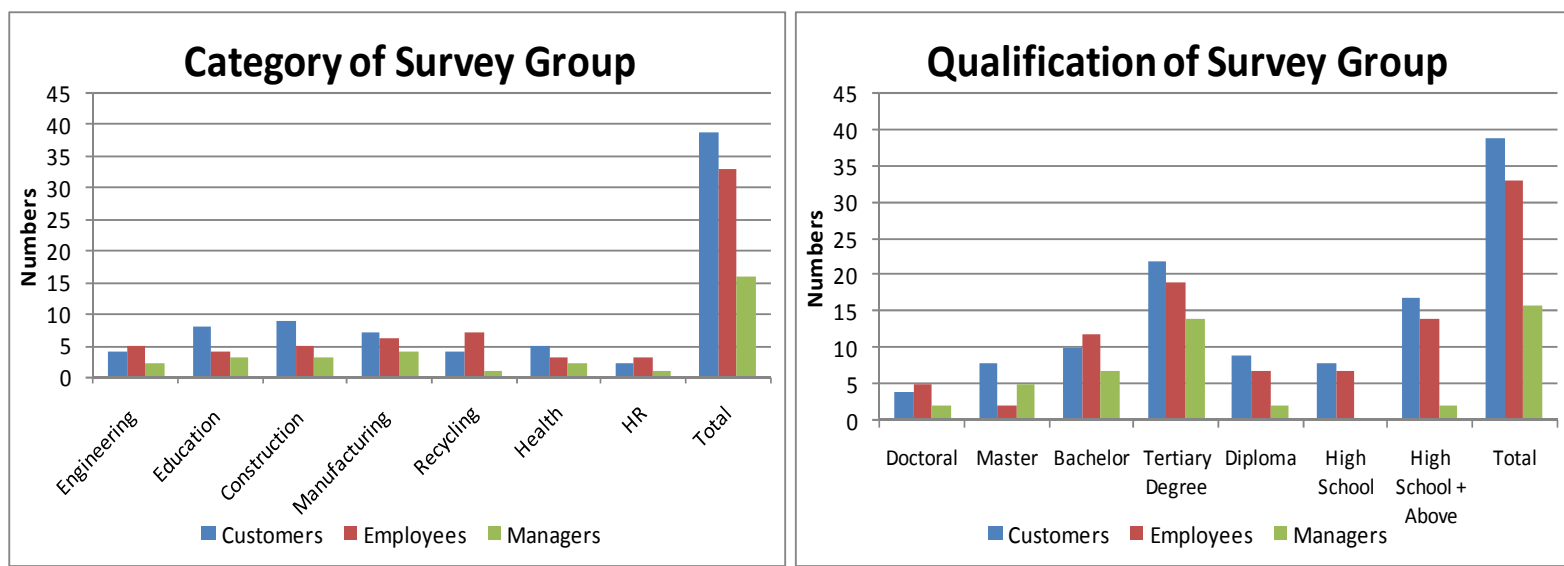

Figure 1(a)(b): Histogram of Survey Group Background and Qualifications

\begin{tabular}{|l|c|c|c|c|c|c|}
\hline Type of Industry & Public & Private & Customers & Employees & Managers & Total \\
\hline Engineering & 6 & 5 & 4 & 5 & 2 & 11 \\
\hline Education & 9 & 6 & 8 & 4 & 3 & 15 \\
\hline Construction & 9 & 8 & 9 & 5 & 3 & 17 \\
\hline Manufacturing & 10 & 7 & 7 & 6 & 4 & 17 \\
\hline Recycling industry & 7 & 5 & 4 & 7 & 1 & 12 \\
\hline Health & 4 & 6 & 5 & 3 & 2 & 10 \\
\hline Human resource & 2 & 4 & 2 & 3 & 1 & 6 \\
\hline Total & 47 & 41 & 39 & 33 & 16 & 88 \\
\hline$\%$ & & & 44.25 & 37.50 & 18.25 & 100 \\
\hline
\end{tabular}

Table 1: Categorising Survey Groups to Industry and Economic Sectors

\begin{tabular}{|l|c|c|c|c|c|c|c|c|}
\hline \multicolumn{1}{|c|}{ Qualifications } & Customers & \% & Employee & \% & Managers & \% & Total & \% \\
\hline Doctoral & 4 & 36.36 & 5 & 45.45 & 2 & 18.18 & 11 & 12.50 \\
\hline Master & 8 & 53.33 & 2 & 13.33 & 5 & 33.33 & 15 & 17.05 \\
\hline Bachelor & 10 & 34.48 & 12 & 41.38 & 7 & 24.14 & 29 & 32.95 \\
\hline Higher degree & 22 & 40.00 & 19 & 34.55 & 14 & 25.45 & 57 & 62.50 \\
\hline Diploma & 9 & 50.00 & 7 & 38.88 & 2 & 11.11 & 18 & 20.45 \\
\hline Higher school & 8 & 53.33 & 7 & 46.67 & 0 & 0 & 15 & 17.05 \\
\hline High school \& above & 17 & 51.51 & 14 & 42.42 & 2 & 6.06 & 33 & 37.50 \\
\hline Total & 39 & & 33 & & 16 & & 88 & 100.00 \\
\hline
\end{tabular}

Table 2 Categorising Survey Groups to Educational Level

\section{ANALYSIS OF THE RESULTS}

The questionnaire including six general questions was sent by hand, electronically, and by post or facsimile (Table 3). Table 4 shows responses of the three groups to the six general questions aimed at investigating:

1. The understanding and contexts of Business Process Re-engineering in their business domain;

2. The need for recycling resources and fortuitous improvements in efficiency;

3. The acceptance of new technology in their current systems;

4. Overall mentality about changes in management and impacts on current work structures;

5. The correlation between process performance and product quality, both in terms of direct and indirect influences and;

6. The acceptance of changes in management, in terms of the change in strategies and ideas. (Refer to appendix).
In particular, the survey indicates that while respondents were overall positive about the need for management to change their work ideas and structures, a lesser number acknowledged there is a correlation between process performance and product quality. Furthermore, a lesser number understood the context of business process re-engineering in their current work practice, indicating a reduced appreciation of how proper BPR practice can influence improvement in product quality and control.

In these circumstances, there is a concern that while people acknowledge that change is necessary in the mindset of management, a lesser number indicate an empowerment to explore how business process reengineering can positively affect their current business strategies. Managers are not actively responsive to realising that Information technology serves as a critical resource when factoring business process strategies, and how supply-chain processes can be enhanced with Service Oriented Architectures (SOA). 


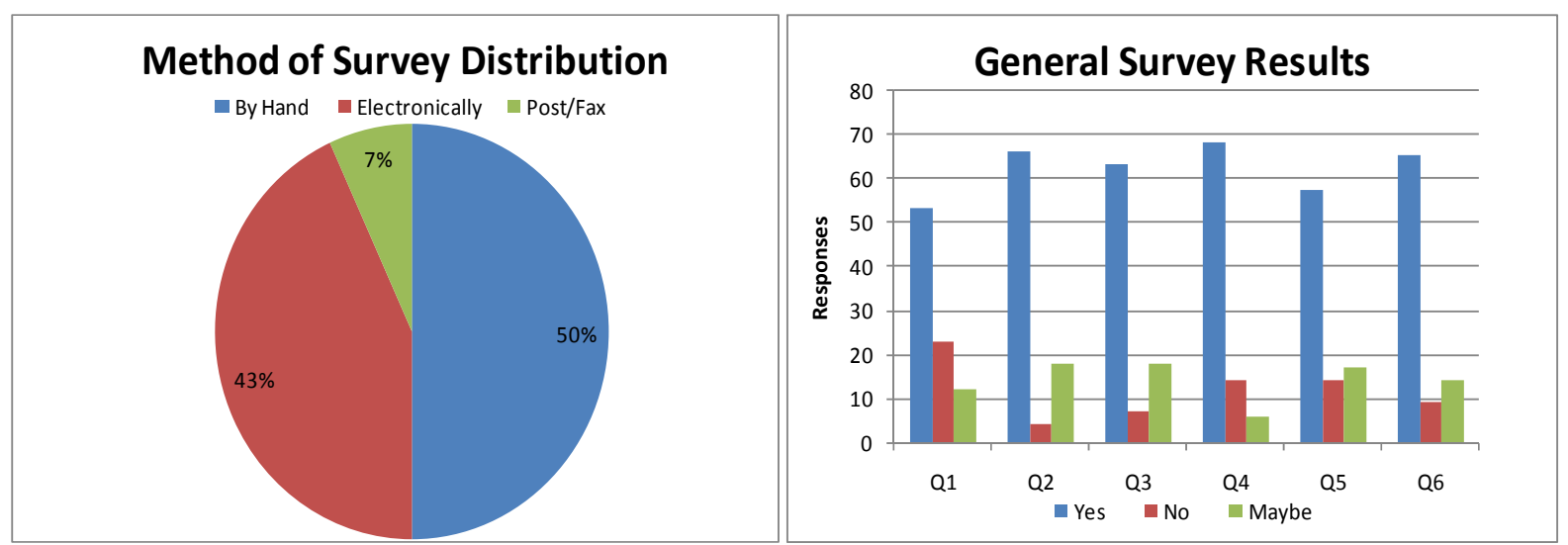

Figure 2(a)(b): Chart of Survey Distribution and Histogram of Survey Results

\begin{tabular}{|l|l|l|l|l|}
\hline & By Hand & Electronic / Email & Postal / Faxes & Total \\
\hline Number & 44 & 38 & 6 & 88 \\
\hline$\%$ & $50 \%$ & $43.18 \%$ & $6.82 \%$ & $100 \%$ \\
\hline
\end{tabular}

Table 3 Distribution Methods of Survey Questionnaire

\begin{tabular}{|c|c|c|c|c|c|c|c|c|}
\hline General Question & Q1 & Q2 & Q3 & Q4 & Q5 & Q6 & Total & \% \\
\hline Yes & 53 & 66 & 63 & 68 & 57 & 65 & 372 & 70.45 \\
\hline$\%$ & 60.23 & 75.00 & 71.57 & 77.27 & 64.77 & 73.86 & & \\
\hline No & 23 & 4 & 7 & 14 & 14 & 9 & 71 & 13.45 \\
\hline$\%$ & 26.14 & 4.55 & 7.95 & 15.91 & 15.91 & 10.23 & & \\
\hline Maybe & 12 & 18 & 18 & 6 & 17 & 14 & 85 & 16.10 \\
\hline$\%$ & 13.64 & 20.45 & 20.45 & 6.82 & 19.32 & 15.91 & & \\
\hline
\end{tabular}

Table 4 Responses of Groups to General Questions

\section{CONCLUSION}

The responses show attitudes of the respondents (managers, employees and customers) towards the issues of understanding BPR, acceptance of new technologies and mentalities about changes in management. Responses revealed that there is a positive attitude towards these issues, with $75 \%$ of respondents agreeing with the importance of Recycling business approaches and $71.57 \%$ respondents would readily accept new technologies. However, this is contradicted by the fact that only $60.32 \%$ of respondents understood and had a positive attitude towards Business Process Re-engineering. Furthermore, only $64.77 \%$ of the respondents understood the importance of the correlation between process performance and product quality.

The contrast between respondents agreeing with acceptance of new technologies, but at the same time a lower percentage of respondents do not see the how business process re-engineering can improve product quality is a notable difference of opinion among respondents.

This difference could be explained by the fact that people do not see their own roles in promoting or having any positive influence on the overall situation. The discrepancy of the results indicates that there is a degree of disconnect with managers understanding the nature of their current business processes on product delivery and quality; or employees and customers are not adequately voicing their concerns to improve product service and quality above minimum expectations, or a combination of both these factors.

A strategy focussed on improving current business process strategy needs to be maintained in order to improve performance thresholds on environmental concerns, such as recycling resources and minimising wastage through continuous monitoring and control, which will eventually result in improving the financial performance of the organisation. Furthermore, this strategy needs to be reinforced in all levels of the organisation for any long-term benefit. Environmental sustainability in any industry is critical in all regards, not just in terms of credentials and marketability, but also the economic performance of the organisation.

In conclusion, while there is an overall positive awareness of the importance of BPR between the three groups investigated in this study, the culture of improving current business process models in the industries of Kingdom of Saudi Arabia requires greater transparency for respondents to have a positive influence in promoting BPR strategies. The verification and validation of operational systems relies on proactive SOA middleware infrastructure that can adhere to corporate policy governance and enduring environmental sustainability. 


\section{REFERENCES}

[1] Kutschker M. (1994), Re-engineering of Business Processes in Multinational Corporations, Research presented at the Institute's International Research Conference, 2 November 1994.

[2] OSD Comptroller Center (2008), Reengineering: A Radical Approach to Business Process Redesign, URL: http://www.defenselink.mil/comptroller/icenter/l earn/reeng.htm, Last Visited 14 May 2008

[3] Encyclopaedia of Management, (2008) Business Processes Reengineering, URL: http://www.referenceforbusiness.com/manageme nt/Bun-Comp/Business- $\quad$ ProcessReengineering.html, Last Visited 6 May 2008

[4] Gunasekaran A., Kobu B. (2002), Modelling and Analysis of Business Process Reengineering, International Edition, Vol. 40, No. 11.

[5] Kim H.M., Ramkaran R. (2004), Business Process Management Journal, Vol. 10, Issue 1.

[6] Dubrovski D. (2005), Restructuring and Business Reengineering in Integrative Processes, Managing Global Transitions, Volume 3, Number 1, Spring 2005, pp81.

[7] Xenakis A., and Macintosh A. (2005), Using Business Process Re-engineering (BPR) for the Effective Administration of Electronic Voting, Electronic Journal of e-Government Volume 3 Issue 2 2005, pp94-95

[8] Gunasekaran A., B. Kobu (2002), Citation from [4], pp25-24.

[9] Hammer M (1990), Reengineering Work: Don't Automate, Obliterate, Harvard Business Review, July-August 1990, pp104-110.

[10] Jahnke B, Clifford T., Y. Tjiok (2002), Business Process Reengineering and Software Systems Strategy, Abteilung für Betriebswirtschaftslehre insb Wirtschaftsinformatik Universität Tübingen.

[11] Berztiss A. (1997), Software Methods for Business Reengineering, Springer Publishing, p10.

[12] Boudreau M., Robey D. (1996), Coping with Contradictions in Business Process Reengineering, Information Technology \& People, MCB University Press, Vol. 9 No. 4 1996, p40.

[13] Muthu S., Whitman L., Hossein Cheraghi S. (1999), Business Process Reengineering: A Consolidated Methodology, Proceedings of The 4th Annual International Conference on Industrial Engineering Theory, Applications and
Practice November 17-20 1999, San Antonio, Texas, USA, p2.

[14] Weicher M., Chu W.W., Ching W., et al (1995), Business Process Reengineering Analysis and Recommendations, A paper written by a group of MBA and MS students at Baruch College, City University of New York, 1995, URL: www.netlib.com. Last Visited 8 May 2008

[15] City of San Diego (2008), 2008 Fiscal Year Annual Budget, Business Process Reengineering, p32

[16] Fitzgerald B., Murphy C. (1996), Business Process Reengineering, The Creation and Implementation of a Methodology, Executive Systems Research Centre, University College, Cork, Ireland.

[17] United States General Accounting Office (1997), Accounting and Information Management Division Business Process Reengineering Assessment Guide, May 1997, Version 3.

[18] BPR Online Learning Centre (2008), URL: http://www.isixsigma.com/offsite.asp?A=Fr, http://www.prosci.com/factors.htm, on 2nd March, 2008.

[19] Fitzgerald B., Murphy C., Citation from [16], p2.

[20] Hammer M., Champy J. (2001), Reengineering the Corporation: A Manifesto for Business Revolution, HarperCollins Business Publishing, 2001

[21] Akkermans H., Baida Z., Gordijn J., Pena N., Altuna A., Laresgoiti (2004). Value webs: Using Ontologies to Bundle Real-World Services, IEEE Intelligent Systems July-Aug 2004, pp57-66. 


\section{APPENDIX: Summary of Survey Findings from KSA Focus Group}

The survey was conducted in the Kingdom of Saudi Arabia (KSA) towards the end of 2007 to investigate the level of awareness and understanding of BPR among customers, employees, and managers of different industries covering both public and private sectors. There were total 113 respondents of which 88 completed the survey forms and 25 did not answer all the questions and they were considered as partial respondents. 25 participants who did not answer all the questions of the general question section were considered non-participants and data analysis was carried out for only 88 participants who answered all the questions. The number of public and private companies participated in the survey was equal and most respondents were from manufacturing industries followed by engineering industry. The number of female respondents was significantly less than male respondents indicating women could be less likely in the industry places of KSA communities (see table 3).

A questionnaire was developed which consisted of 6 general questions and 10 specific questions. The specific questions were formulated for each specific group of the participants in the survey that included customers, employees, and managers. The participants of all the groups had to answer all general questions; however, the respondents belonging to one particular group had to respond to the questions specified for them only. The specific questions helped to find out whether the understanding and mentality in the field of BPR varied across groups (see sample questionnaire). Majority of the questionnaires were distributed personally by hand and a comparable number were distributed electronically using email and a small number were either posted or faxed to the respondents (see table 1 ). The responses received were dated and filed. The education levels of the participants were analysed. The levels of education of the participants varied; however, majority had bachelor and higher degrees. The respondents across all sections had comparable levels of education. More employees had tertiary degrees compared to the managers and more customers had university degrees compared to both managers and employees. This may indicate a general increase of literacy level in the communities of KSA (see table 2) in the recent years. Also, most respondents were vocationally and technically trained and the majority managers were from combined engineering and technically trained groups indicating that vocational and technical trainings were attracting more people and becoming a significant education component in KSA (see table 4).

One important observation of this study was that although majority respondents were of Saudi origin, a significant number of respondents including in the managerial positions were form international backgrounds indicating multicultural workplace environment in Saudi Arabia. The number of employees from ethnic backgrounds appeared to be relatively and consistently higher compared to the numbers of managers and customers.

The general questions were aimed at investigating the understanding of BPR, need for recycling, views on acceptance of new technology, mentality about changes in management; correlation between process performance and product quality and acceptance of changes in the management. Analysis of the responses of the general questions shows that majority indicated they understood BPR, and agreed that recycling was important in the industries of KSA. Likewise, a significant majority were found in favour of accepting new technology and changes in the management for to ensure better process performance and product quality of the industries (see table 6).

In relation to specific questions, majority of the respondents across groups (customers, employees and managers) answered all 10 questions relevant to them whereas a minority (6.59\%) failed to answer all 10 questions although they answered most of the questions. So, the total number of responses was quite satisfactory and might support the significance of the findings. Failure to respond to any particular question appeared to be due to lack of understanding of the concept of the question (see tables 8, 9 and 10). The customers were asked to respond to a number of issues expressing their views and understanding such as qualities of new products, management's responses to product quality concerns, concerns about customer's rights, adaptation of new methods/ technologies, importance of environmental friendliness, support for "environmental friendly" industries, product brands and environmental friendliness, role of better management for improvement, response to company close down and impressions about workplace environments.

The employees responded to a number of issues expressing their views and understanding such as importance as an employee, importune of employees' opinions, relationship with management, importance of employee's concerns, work satisfaction, training opportunities and outcomes, use of employee's skills, thinking differently, satisfaction with administration and Suggestions about changes at work place. The managers also responded to a number of questions in relation to vision for the growth of the company, proposed strategic changes, importance of employees' satisfaction, ways for employees' satisfaction, acceptance of new technology, importance of restructuring and process recycling, support for restructuring and redesigning, identifying root causes of problems, assessing potentials for changes, and participation in previous surveys and their impacts. 
I. Methods of distribution of the survey questionnaire

\begin{tabular}{|c|c|c|c|c|c|}
\hline Methods of distributing & By Hand & Electronic & Post/Fax & Total & Notes \\
\cline { 2 - 6 } Questionnaire/Survey & 44 & 38 & 6 & $113-25=$ & 25 \\
\cline { 2 - 4 } & $50 \%$ & $43.18 \%$ & $6.82 \%$ & 88 & Not complete \\
\hline
\end{tabular}

Table 5: Shows methods of distribution of the survey questionnaire.

Most questionnaires were distributed by hand followed by electronic transfer. A small number of questionnaires were also sent by post or by fax.

\section{Education Levels of Participants}

\begin{tabular}{|c|c|c|c|c|c|c|c|c|}
\hline Qualifications & Customers & \% & Employee & \% & Manager & \% & Total & \% \\
\hline Doctoral & 4 & 36.36 & 5 & 45.45 & 2 & 18.18 & 11 & 12.5 \\
\hline Masters & 8 & 53.33 & 2 & 13.33 & 5 & 33.33 & 15 & 17.05 \\
\hline Bachelors & 10 & 34.48 & 12 & 41.38 & 7 & 24.14 & 29 & 32.95 \\
\hline Higher Degree & 22 & 40 & 19 & 34.55 & 14 & 25.45 & 55 & 62 \\
\hline Diploma & 9 & 50 & 7 & 38.88 & 2 & 11.11 & 18 & 20.45 \\
\hline Higher school & 8 & 53.33 & 7 & 46.67 & 0 & 0 & 15 & 17.05 \\
\hline $\begin{array}{c}\text { High school } \\
\text { and above }\end{array}$ & 17 & 51.51 & 14 & 42.42 & 2 & 6.06 & 33 & 37.5 \\
\hline Total & 39 & & 33 & & 16 & & 88 & $100 \%$ \\
\hline
\end{tabular}

Table 6: Shows the education levels of the participants

Among 88 participants majority (62.5\%) had Bachelor and higher degrees and the rest had high school to diploma level education. $40 \%$ of the customers, $34.55 \%$ of the employees and $25.45 \%$ of the managers had tertiary education (Bachelor, Master and Doctoral degrees). It appears that the customers were also well educated. While more employees had higher education done compared to the managers might indicate that many of the managers could have been in the senior position because of their experience and expertise and also some of them might have been the owners. None of them who had only high school/diploma level education was at the manager level. However, high school level education was comparable between customers and employees.

\section{Types of Industries}

\begin{tabular}{|c|c|c|c|c|c|c|c|c|c|}
\hline $\begin{array}{l}\text { Type of } \\
\text { Industry }\end{array}$ & Public & Private & \multicolumn{2}{|c|}{$\begin{array}{c}\text { Customers } \\
\text { Male/Female }\end{array}$} & \multicolumn{2}{|c|}{$\begin{array}{c}\text { Employee } \\
\text { Male/Female }\end{array}$} & \multicolumn{2}{|c|}{$\begin{array}{c}\text { Manager } \\
\text { Male/Female }\end{array}$} & Total \\
\hline Engineering & 6 & 5 & 4 & 0 & 3 & 2 & 2 & 0 & 11 \\
\hline Education & 9 & 6 & 5 & 3 & 2 & 2 & 2 & 1 & 15 \\
\hline Construction & 9 & 8 & 7 & 2 & 3 & 2 & 3 & 0 & 17 \\
\hline Manufactures & 10 & 7 & 5 & 2 & 5 & 1 & 3 & 1 & 17 \\
\hline $\begin{array}{l}\text { Recycling } \\
\text { Industry }\end{array}$ & 7 & 5 & 4 & 0 & 5 & 2 & 1 & 0 & 12 \\
\hline Health & 4 & 6 & 3 & 2 & 1 & 2 & 1 & 1 & 10 \\
\hline $\begin{array}{c}\text { Human } \\
\text { Resources }\end{array}$ & 2 & 4 & 2 & 0 & 2 & 1 & 1 & 0 & 6 \\
\hline Total & 47 & 41 & $\begin{array}{r}30 \\
76.92 \% \\
44 . \\
\end{array}$ & \begin{tabular}{|c|}
9 \\
$23.08 \%$ \\
$\%$ \\
\end{tabular} & \begin{tabular}{r|}
21 \\
$63.64 \%$ \\
33 \\
37.5 \\
\end{tabular} & \begin{tabular}{|l|}
12 \\
$36.36 \%$ \\
3 \\
$\%$ \\
\end{tabular} & \begin{tabular}{|r|}
13 \\
$70.83 \%$ \\
18.8 \\
\end{tabular} & \begin{tabular}{|c|}
\multicolumn{1}{|c|}{3} \\
$29.17 \%$ \\
6 \\
$0 \%$ \\
\end{tabular} & $\begin{array}{c}88 \\
100 \%\end{array}$ \\
\hline
\end{tabular}

Table 7: Shows types of industries and number of men and women among managers, employees and customers in each type of industry.

The number of public and private companies equals on an average. The most respondents were from manufacturing industries followed by engineering industry and the minimum was from human resource. The number of participants from education, construction and recycling industries were comparable. The number of female respondents from each type of industry was significantly less than male respondents which might indicate that women are less likely to be in the industry places in the Saudi communities. 


\section{Respondents from Different Professions}

\begin{tabular}{|c|c|c|c|c|c|}
\hline Professions & Customers & Employees & Managers & Total & Total of \% \\
\hline Engineering & $\begin{array}{c}12 \\
63.16 \%\end{array}$ & $\begin{array}{c}5 \\
26.32 \%\end{array}$ & $\begin{array}{c}2 \\
10.53 \%\end{array}$ & 19 & $21.59 \%$ \\
\hline Technical & $\begin{array}{c}20 \\
35.71 \%\end{array}$ & $\begin{array}{c}24 \\
42.86 \%\end{array}$ & $\begin{array}{c}12 \\
21.43 \%\end{array}$ & 56 & $63.64 \%$ \\
\hline $\begin{array}{c}\text { Other } \\
\text { Professions }\end{array}$ & $\begin{array}{c}7 \\
53.85 \% \\
\end{array}$ & $\begin{array}{c}4 \\
30.77 \% \\
\end{array}$ & $\begin{array}{c}2 \\
15.38 \% \\
\end{array}$ & 13 & $14.77 \%$ \\
\hline Total & 39 & 33 & 16 & 88 & $100 \%$ \\
\hline$\%$ & 44.32 & 37.5 & 18.18 & \multicolumn{2}{|c|}{100} \\
\hline
\end{tabular}

Table 8: Shows number of respondents from different professions

Most respondents were from vocational and technically trained group. The number of participants from engineering and total of other professions were comparable. However, majority of the managers were from combined engineering and technically trained groups.

\section{Nationalities of the Respondents}

\begin{tabular}{|c|c|c|c|c|}
\hline Nationality & Customers & Employees & Manager & Total \\
\hline Saudi & 17 & 14 & 6 & 37 \\
& $45.95 \%$ & $37.84 \%$ & $16.22 \%$ & $42.05 \%$ \\
\hline Indian & 6 & 7 & 2 & 15 \\
& $40 \%$ & $46.67 \%$ & $13.33 \%$ & $17.05 \%$ \\
\hline Syrian & 5 & 4 & 2 & 11 \\
& $45.45 \%$ & $36.36 \%$ & $18.18 \%$ & 10 \\
\hline Egyptian & 5 & 3 & 2 & $11.36 \%$ \\
\hline Jordanian & $50 \%$ & 3 & 2 & 9 \\
& 4 & $33.33 \%$ & $22.22 \%$ & $10.23 \%$ \\
\hline Lebanese & 2 & 2 & 2 & 6 \\
& $33.33 \%$ & $33.33 \%$ & $33.33 \%$ & $6.82 \%$ \\
\hline Total & 39 & 33 & 16 & 88 \\
$\%$ & $44.32 \%$ & $37.5 \%$ & $18.18 \%$ & $100 \%$ \\
\hline
\end{tabular}

Table 9: Shows nationalities of the respondents

Most respondents were of Saudi background. However, the figure shows that there are people from international backgrounds including in the managerial positions indicating multicultural workplace environment in Saudi Arabia. The number of employees from ethnic back grounds appears to be relatively and consistently higher compared to the numbers of managers and customers.

\section{Responses of General Questions}

\begin{tabular}{|c|c|c|c|c|c|c|c|}
\hline $\begin{array}{c}\text { General } \\
\text { Questions }\end{array}$ & $\begin{array}{c}\text { Q1 } \\
\text { Understand } \\
\text { BPR }\end{array}$ & $\begin{array}{c}\text { Q2 } \\
\text { Need for } \\
\text { Recycling }\end{array}$ & $\begin{array}{c}\text { Q3 } \\
\text { Acceptance } \\
\text { of new } \\
\text { technology }\end{array}$ & $\begin{array}{c}\text { Q4 } \\
\text { Mentality } \\
\text { about } \\
\text { Changes in } \\
\text { management }\end{array}$ & $\begin{array}{c}\text { Q5 } \\
\text { Correlation } \\
\text { between } \\
\text { process } \\
\text { performance } \\
\text { and product } \\
\text { quality }\end{array}$ & $\begin{array}{c}\text { Q6 } \\
\text { Acceptance of } \\
\text { Changes in } \\
\text { management }\end{array}$ & $\begin{array}{c}\text { Total } \\
\text { no of } \\
\text { answers }\end{array}$ \\
\hline Yes & 53 & 66 & 63 & 68 & 57 & 65 & 372 \\
\hline$\%$ & 60.23 & 75 & 71.57 & 77.27 & 64.77 & 73.86 & $70.45 \%$ \\
\hline No & 23 & 4 & 7 & 14 & 14 & 9 & 71 \\
\hline Maybe & 26.14 & 4.55 & 7.95 & 15.91 & 15.91 & 10.23 & $13.45 \%$ \\
\hline$\%$ & 12 & 18 & 18 & 6 & 17 & 14 & 85 \\
\hline Total & 88 & 20.45 & 20.45 & 6.82 & 19.32 & 15.91 & $16.10 \%$ \\
\hline
\end{tabular}

Table 10: Summarises the responses of 6 general questions 
The responses show attitudes of the respondents (managers, employees and customers) towards a number of relevant issues. To each question they answered either yes (indicating positive attitude) or no (indicating negative attitude) or maybe (not sure about). Majority (60.23\%) indicated they understood BPR, (75\%) agreed with the importance of recycling. (71.57\%) would readily accept new technology. Changes in the management were viewed positively by $(77.27 \%)$ whereas, $(73.86 \%)$ of the respondents would have accepted changes in the management. (64.77\%) of the respondents said they understood the importance of the correlation between process performance and product quality.

\section{Responses for Specific Questions to Customers, Employees and Managers}

\begin{tabular}{|c|c|c|c|c|c|c|c|c|c|c|c|c|}
\hline $\begin{array}{c}\text { Specific } \\
\text { Question }\end{array}$ & Q1 & Q2 & Q3 & Q4 & Q5 & Q6 & Q7 & Q8 & Q9 & Q10 & Total & Note \\
\hline Customer & 39 & 39 & 37 & 39 & 39 & 37 & 35 & 37 & 38 & 38 & \multirow{2}{*}{$\begin{array}{c}378 \\
100 \% \\
\end{array}$} & \\
\hline$\%$ & 10.32 & 10.32 & 9.79 & 10.32 & 10.32 & 9.79 & 9.26 & 9.79 & 10.05 & 10.05 & & \\
\hline Employee & 30 & 29 & 30 & 31 & 32 & 25 & 29 & 32 & 27 & 33 & \multirow{2}{*}{$\begin{array}{c}298 \\
100 \%\end{array}$} & \\
\hline$\%$ & 10.07 & 9.73 & 10.07 & 10.40 & 10.74 & 8.39 & 9.73 & 10.74 & 9.06 & 11.07 & & \\
\hline $\begin{array}{c}\text { Manager/ } \\
\text { Staff }\end{array}$ & 14 & 15 & 15 & 15 & 14 & 16 & 16 & 13 & 16 & 12 & \multirow[t]{2}{*}{$\begin{array}{c}146 \\
100 \%\end{array}$} & \\
\hline$\%$ & 9.59 & 10.27 & 10.27 & 10.27 & 9.59 & 10.96 & 10.96 & 8.91 & 10.96 & 8.22 & & \\
\hline Total & \multicolumn{10}{|c|}{$822-80=58$} & 822 & 8 \\
\hline
\end{tabular}

Table 11: Shows total number of responses for each specific question to customers, employees and the managers.

- The highest number of respondents was from customers which maximum number of respondents was 39 to question 1, 2, 4 \& 5 and minimum (35) to question 7. 38 responded to questions 9 \& 10; whereas 37 responded to questions $3,6 \& 8$.

- The second highest respondents were from employees, maximum number of respondents was 33 to question 10 and minimum (25) to question 6.32 responded to questions 5 \& 8; 31 responded to questions 4 ; 30 responded to question $1 \& 3 ; 29$ responded to questions $2 \& 7 ; 27$ responded to question 9.

- $\quad$ The number of managers responded was the least. Maximum number of respondents was 16 to question 6, 7 \& 9 and minimum (12) to question 10.15 responded to questions 2, 3 \& 4; 14 responded to questions 1 \& 5 , 13 responded to question 8 .

- The total responses to all 10 questions across groups (customers, employees and managers) should have been 880 (total 88 respondents X 10 questions); however, the total number of responses were 822. 58 questions in total across groups were not answered most likely because they could not understand the meaning of the questions. However, this number was small $(6.59 \%)$ compared to the total responses (93.41\%).

VIII. The Respondents (Customers) Understanding of Questions

\begin{tabular}{|c|c|c|c|c|c|c|c|c|c|c|c|}
\hline $\begin{array}{c}\text { Specific } \\
\text { Question }\end{array}$ & Q1 & Q2 & Q3 & Q4 & Q5 & Q6 & Q7 & Q8 & Q9 & Q10 & Total \\
\hline Yes & 27 & 29 & 32 & 33 & 28 & 29 & 26 & 32 & 25 & 28 & 289 \\
\hline$\%$ & 69.23 & 74.36 & 86.49 & 84.62 & 71.79 & 78.38 & 74.29 & 86.49 & 65.79 & 73.68 & 76.46 \\
\hline No & 7 & 7 & 2 & 3 & 3 & 3 & 3 & 2 & 11 & 7 & 48 \\
\hline$\%$ & 17.95 & 17.95 & 5.41 & 7.69 & 7.69 & 8.11 & 8.57 & 5.41 & 28.95 & 18.42 & 12.69 \\
\hline Maybe & 5 & 3 & 3 & 3 & 8 & 5 & 6 & 3 & 2 & 3 & 41 \\
\hline$\%$ & 12.82 & 7.69 & 8.11 & 7.69 & 20.51 & 13.51 & 17.14 & 8.11 & 5.26 & 7.89 & 10.85 \\
\hline Total & 39 & 39 & 37 & 39 & 39 & 37 & 35 & 37 & 38 & 38 & 378 \\
\hline$\%$ & \multicolumn{9}{|c|}{$100 \%$} \\
\hline
\end{tabular}

Table 12: Shows whether respondents (Customers) understood questions

Q1. Qualities of New products

Q2. Product quality concerns and management response

Q3. Concerns about customer's rights

Q4. Adaptation of new methods / technologies

Q5. Important environmental friendliness
Q6. Support for “environmentally friendly” industries

Q7. Product brands and environmental friendliness

Q8. Management for improvement in advice

Q9. Response to company close down

Q10. Impressions about workplace 
The respondents who understood the questions and therefore responded to them are categorised as 'yes' and who did not understand the questions and therefore did not respond to them are categorised as 'no' and those who attempted to respond to the questions, but could not complete the responses are categorised as 'maybe'. The results show that a significant majority of the respondents understood the questions and responded to them.

\section{The Respondents (Employees) Understanding of Questions}

\begin{tabular}{|c|c|c|c|c|c|c|c|c|c|c|c|}
\hline $\begin{array}{c}\text { Specific } \\
\text { Question }\end{array}$ & Q1 & Q2 & Q3 & Q4 & Q5 & Q6 & Q7 & Q8 & Q9 & Q10 & Total \\
\hline Yes & 24 & 20 & 21 & 21 & 20 & 14 & 17 & 25 & 15 & 25 & 202 \\
\hline$\%$ & 80 & 68.97 & 70 & 67.74 & 62.5 & 56 & 58.62 & 78.13 & 55.55 & 75.76 & 67.79 \\
\hline No & 4 & 6 & 6 & 7 & 7 & 9 & 10 & 3 & 5 & 4 & 61 \\
\hline$\%$ & 13.33 & 20.69 & 20 & 22.58 & 21.88 & 36 & 34.48 & 9.37 & 18.52 & 12.12 & 20.47 \\
\hline Maybe & 2 & 3 & 3 & 3 & 5 & 2 & 2 & 4 & 7 & 4 & 35 \\
\hline$\%$ & 6.67 & 10.34 & 10 & 9.68 & 15.63 & 8 & 6.90 & 12.5 & 25.93 & 12.12 & 11.74 \\
\hline Total & 30 & 29 & 30 & 31 & 32 & 25 & 29 & 32 & 27 & 33 & 298 \\
\hline$\%$ & \multicolumn{7}{|c|}{$100 \%$} \\
\hline
\end{tabular}

Table 13: Shows whether respondents (Employees) understood questions

Q1. Importance as an employee

Q2. Importance of employees opinions

Q3. Relationship with management

Q4. Importance of employee's concerns

Q5. Work satisfaction
Q6. Training opportunities and outcomes

Q7. Use of employee's skills

Q8. Thinking differently

Q9. Satisfaction with administration

Q10. Suggestions about changes at work place

Like before in Table 8, the respondents who understood the questions and therefore responded to them are categorised as 'yes' and who did not understand the questions and therefore did not respond to them are categorised as 'no' and those who attempted to respond to the questions, but could not complete the responses are categorised as 'maybe'. The results show that a significant majority of the respondents understood the questions and responded to them.

\section{The Respondents (Managers) Understanding of Questions}

\begin{tabular}{|c|c|c|c|c|c|c|c|c|c|c|c|}
\hline $\begin{array}{c}\text { Specific } \\
\text { Question }\end{array}$ & Q1 & Q2 & Q3 & Q4 & Q5 & Q6 & Q7 & Q8 & Q9 & Q10 & Total \\
\hline Yes & 8 & 7 & 12 & 12 & 10 & 14 & 13 & 11 & 13 & 7 & 107 \\
\hline$\%$ & 57.14 & 46.66 & 80 & 80 & 71.42 & 87.5 & 81.25 & 84.62 & 81.25 & 58.33 & 73.29 \\
\hline No & 4 & 4 & 2 & 3 & 2 & 0 & 1 & 0 & 1 & 2 & 19 \\
\hline$\%$ & 28.57 & 26.67 & 13.33 & 20 & 14.29 & 0 & 6.25 & 0 & 6.25 & 16.67 & 13.01 \\
\hline Maybe & 2 & 4 & 1 & 0 & 2 & 2 & 2 & 2 & 2 & 3 & 20 \\
\hline$\%$ & 14.29 & 26.67 & 6.67 & 0 & 14.29 & 12.5 & 12.5 & 15.38 & 12.5 & 25 & 13.70 \\
\hline Total & 14 & 15 & 15 & 15 & 14 & 16 & 16 & 13 & 16 & 12 & 146 \\
\hline$\%$ & \multicolumn{7}{|c|}{$100 \%$} \\
\hline
\end{tabular}

Table 14: Shows whether respondents (Managers) understood questions

Q1. Vision for the growth of company

Q2. Proposed strategic changes

Q3. Importance of employees' satisfaction

Q4. Ways for employees' satisfaction

Q5. Acceptance of new technology
Q6. Importance of restructuring and process recycling

Q7. Support for restructuring and redesigning

Q8. Identifying root causes of problems

Q9. Assessing potentials for changes

Q10. Previous surveys and impacts

Like before (table 8 \& 9) the respondents who understood the questions and therefore responded to them are categorised as 'yes' and who did not understand the questions and therefore did not respond to them are categorised as 'no' and those who attempted to respond to the questions, but could not complete the responses are categorised as 'maybe'. The results show that a significant majority of the respondents understood the questions and responded to them. Figures 8, 9 and 10 clearly indicate that the majority participants understood and responded to the questions relevant to them. This may indicate that the findings are significant. 